University of Nebraska - Lincoln

DigitalCommons@University of Nebraska - Lincoln

January 2000

\title{
Process-Oriented Environmental Change Curriculum-Development Workshops
}

David C. Gosselin

University of Nebraska - Lincoln, dgosselin2@unl.edu

Sherri Lowrey

The Woodlands, TX

Steven John Meyer

University of Nebraska - Lincoln

Follow this and additional works at: https://digitalcommons.unl.edu/natrespapers

Part of the Natural Resources and Conservation Commons

Gosselin, David C.; Lowrey, Sherri; and Meyer, Steven John, "Process-Oriented Environmental Change Curriculum-Development Workshops" (2000). Papers in Natural Resources. 134.

https://digitalcommons.unl.edu/natrespapers/134

This Article is brought to you for free and open access by the Natural Resources, School of at DigitalCommons@University of Nebraska - Lincoln. It has been accepted for inclusion in Papers in Natural Resources by an authorized administrator of DigitalCommons@University of Nebraska - Lincoln. 


\section{Process-Oriented Environmental Change Curriculum-Development Workshops}

\author{
David Charles Gosselin \\ Nebraska Earth Sci. Ed. Network \\ 113 Nebraska Hall \\ Inst. of Agriculture \& Natural Resources \\ University of Nebraska - Lincoln \\ Lincoln, Nebraska 68588-0517 \\ gosselin@unlinfo.unl.edu
}

\author{
Sherri Lowrey \\ 58 W. Eden Elm Circle \\ The Woodlands, TX 77381
}

Steven John Meyer

School of Natural Resource Sciences

14 L.W. Chase Hall

Inst. of Agriculture \& Natural Resources

University of Nebraska - Lincoln

Lincoln, Nebraska 68583-0728

\begin{abstract}
To improve scientific literacy, K-12 educators need to: develop the ablility to use and analyze data, incorporate data into their curriculum, and interact with teachers from other disciplines to create interdisciplinary units. A Process-Oriented Environmental Change Education workshop was conducted for eleven interdisciplinary teams, consisting of 21 teachers, in 1997 and 1998. The $\mathrm{Na}^{-}$ tional Science Standards provided the criteria for the organization of the workshop. Inquiry and interpretation exercises helped to expand scientific knowledge and skills as well as the teachers' use of technology. We explicitly discussed the uncertainty of science through group discussions and problem-solving activities. More than $85 \%$ of the teachers thought the goals and objectives of the workshop were clear, the instructional methods suitable for the stated goals, and the content understandable and logically presented. Our teachers were generally not confident in their ability to interpret data, which is not surprising considering that most teachers have not had the opportunity to do this type of analytical work. Clearly, the scientific community needs to find ways to boost teacher confidence in interpreting data using accepted scientific practice if we expect science education to improve.

Keywords: Education - geoscience; education precollege; education - teacher education.
\end{abstract}

\section{INTRODUCTION}

A special report, Geoscience Education: A Recommended Strategy (NSF 1997), highlighted the necessity of providing elementary and secondary students with the opportunity for hands-on/minds-on discovery using the most advanced data and techniques. The report also highlighted the need to develop interdisciplinary curriculum. To accomplish these goals, two specific issues need to be addressed. First, teachers need to develop the relevant skills to incorporate data into their curricula. Second, educators need to interact with teachers from other disciplines to create interdisciplinary units.

Because global environmental change is inherently interdisciplinary and because there are substantial data resources, we developed a workshop entitled Process-Oriented Environmental Change Education to address these two issues. The term, "processoriented," refers to both the process of scientific inquiry and to inquiry-based education. The primary goal of our workshops was to provide an opportunity for K-12 educators to incorporate environmental-change data and information into their current curricula, while supporting the vision of the National Science Education Standards. This paper describes the extent which the workshop helped teachers to 1) enhance their knowledge of environmental change and 2) develop interdisciplinary units.

\section{WORKSHOP DEVELOPMENT}

This workshop is an integral part of the ongoing efforts of the Nebraska Earth Science Education Network (NESEN) to use a variety of strategies to improve science education (Gosselin, 1994; Gosselin and others, 1995a,b,c, 1996, 1997, 1998). To create a professionaldevelopment activity that would be useful to teachers, a two-day planning workshop was convened in September 1996. Workshop participants included: six K-12 educators from rural and urban schools; three 4-H extension educators; four preservice science-teacher educators from the University of Nebraska - Lincoln, University of Nebraska - Kearney, Creighton University, and Nebraska Wesleyan University; three National Institute for Global Environmental Change (NIGEC) scientists; and the director of the Great Plains Regional Center (GPRC). We also included three experts in educational assessment and an expert on the National Science Education Standards.

In our workshop, we recognized that one of the biggest obstacles to improving science education both locally and nationally is the limited formal training and experience many teachers have in "doing science." This limitation has been highlighted by many others (for example, Bower, 1996; Gosselin and others, 1995a, 1996; Groat, 1995; Metzger, 1993; Geary and Zen, 1993; AGI, 1991; Mayer and Armstrong, 1990; Ireton and others, 1996; and NRC, 1996b). A strong recommendation from our advisory group was that multidisciplinary teaching teams be used in the workshop. The reason for having these teams is threefold: 1) students retain information better if it is examined from several different perspectives; 2) teachers can support each other at their schools; and 3) this approach allows for science and other curriculum components to simultaneously evolve in the context of local curriculum requirements. From the exchange of information between these various stakeholders, a four-day workshop was implemented.

\section{WORKSHOP IMPLEMENTATION Participants}

Each team consisted of at least one earth science teacher and at least one teacher from another discipline. 


\section{Process-Oriented Environmental Change Curriculum-Development Workshops}

The earth science teachers were recruited from the NESEN membership list and had actively participated in previous NESEN activities. Each earth science teacher was responsible for recruiting a partner from another discipline, for example, social studies, biological sciences, or mathematics.

Workshops were conducted during August 1997 and 1998. Teachers were paid a stipend, per diem, for lodging and travel costs. One-half of the stipend was provided to the participants shortly after the completion of the workshop. To obtain the second half of their stipend, each team was required to produce a minimum of a five-day interdisciplinary educational unit on environmental change. In addition, the teacher teams were required to present a workshop to at least 10 other educators. All projects have contributed to a portfolio of educational activities available at http: //nesen.unl.edu/nigec.

Eight teachers participated in 1997. Three teams consisted of high-school educators and one team taught fifth and sixth grade. Two Nebraska Cooperative Extension educators also participated. The data from these two educators are not included in the analysis because they were not classroom teachers. In 1998, 13 teachers representing six different rural and urban high schools participated.

\section{Content}

The National Science Education Standards (NRC, 1996a) provided the criteria for the organization and modeling of the scientific process within the workshop. Based on the Standards, our goals for each participant were that they should be able to:

design activities that relate to global environmental change,

promote the development of science skills among students, interpret data,

expand their knowledge of scientific literature and media as well as their ability to access additional information,

build on current science understanding, ability, and attitudes,

challenge students to accept and share responsibility for their own learning,

orchestrate discourse among students about scientific ideas, and

encourage and model skills of scientific inquiry.

In addition to these Standards-based criteria, we also wanted to provide a better understanding of the earth as a system. To accomplish this task, we used an approach modified after Sneider and Golden (1996). This approach recognizes that a change in one part of the system causes changes in other parts of the system, conveying the idea that everything is connected to everything else. Each part of the system functions in response to the exchange of energy and matter.

Both of the workshops began with an introduction to the concept of systems followed by the application of this concept to elements of key subsystems of the earth including the atmosphere, hydrosphere, and biosphere as well as human interaction with these subsystems. Because the participants were from Nebraska, we focused on aspects of these subsystems that would be applicable to their local environments.

Using a variety of activities during the morning of the first day, participants began the workshop by using their observation and communication skills in an activity called "Perspectives: Yours, Mine and Ours." In this activity, each person looks at a given group of objects on a table from different angles. After exchanging observations, it became very clear that everyone had a different perspective about what he or she had observed because of their different backgrounds, interests, and abilities. From here, the teachers began to identify their questions and issues related to global environmental change in the context of role playing and being selected to serve on a mythical advisory panel to the United Nations. In addition, we asked the group what their students should know about environmental change in the context of state and national science-education standards.

On day two, participants were involved in data collection and analysis in the context of identifying potential sources of variability of climatic data. In addition, the teachers examined trends in recent historical climate and carbon-dioxide data. Day three was devoted to applying knowledge about the dynamics of the earth's hydrosphere and acquiring information about their community's hydrologic system. Day four provided an opportunity for participants to develop an understanding of how carbon dioxide acts as a natural fertilizer. In addition, the response of native and agricultural biomes to increasing carbondioxide levels was also considered. During days three and four, time was also provided for curriculum development, especially in the 1998 workshop.

\section{Workshop Assessment}

The following questions provided the framework for our evaluation:

1) How can the quality of the workshop be improved as it proceeds?

2) How did the teachers view the workshop after it concluded?

3) Were the goals and objectives of the workshop met?

4) Are teachers able to design and carry out a unit on global environmental change?

To improve the quality and the process of the workshop, we asked each participant to assess our approach and activities at the end of each morning and afternoon session. Although somewhat different formative survey instruments were used in 1997 and 1998, the primary objective of each was to determine what worked and what should be changed. These data were informally evaluated by the workshop coordinators shortly after each session. Based on this information, modifications were made to the workshop program, especially in 1998 when allowance of additional time to work on curriculum development was strongly suggested by the participants. The formative 


\section{Process-Oriented Environmental Change Curriculum-Development Workshops}

data indicated that we were generally on target with our materials and approach. Information from these formative surveys will not be discussed further.

A wrap-up survey was designed to address questions 2, 3, and 4. Questions in the wrap-up survey sought information regarding workshop content, goals and principles advocated by reform, and teacher efficacy. For each question, teachers were asked to choose among five response categories: "strongly disagree," "disagree," "neutral," "agree," or "strongly disagree." Participants were also asked three qualitative ques" tions concerning their workshop experiences in terms of what was most beneficial, suggestions for improving the workshop, and contributions that the workshop made to the development of an interdisciplinary unit. A detailed analysis of the assessment data as well as the instruments (Lowrey, 1998, 1999) are available upon request from the authors.

\section{DATA SUMMARY}

Overall, $96 \%$ of the teachers were satisfied with their level of participation. Teachers thought the goals and objectives of the workshop were clear, the instructional methods suitable for the stated goals, and the content understandable and logically presented. It was generally agreed the content was not difficult to understand. More importantly, the inquiry and interpretation exercises helped to expand their scientific knowledge and skills. About $70 \%$ of the participants indicated that they would be able to use the workshop materials in their classrooms.

More than three-quarters of the participants indicated that they had learned to use technology to enhance their teaching because of the workshops. These teachers also said they learned new ways to integrate science, technology and other subjects in the classroom. Participants in the 1997 workshop unanimously agreed they would spend more time fostering their students' ability to classify, predict, and hypothesize. In contrast, only $60 \%$ of the 1998 participants reported they would do so. Further analysis indicated that of the eight educators who said they would spend more time cultivating their students' use of the science process skills, seven were science teachers.

Almost all the teachers indicated that they would be able to develop an interdisciplinary unit on global environmental change, but only 15 of 21 teachers (71\%) acknowledged that they had a concrete plan to implement it. Nearly 80\% of the 1998 participants had a specific plan primarily because we provided additional planning time that the 1997 teachers did not have. The teachers said the most beneficial aspect of the workshop was the time to meet, converse, and share with and learn from other teachers.

There were mixed results on the extent to which individuals felt they could create an educational unit on environmental change that implements the science standards. Only $63 \%$ and $46 \%$ in 1997 and 1998, respectively, indicated that they could implement the approaches to learning that are advocated by national and state science standards in their units. These low values are not surprising considering that less than half of the participants were familiar with either the national or state science standards because they represented other disciplines. Another aspect related to implementation of the standards is that less than $60 \%$ of the teachers felt confident they could help their students interpret results consistent with accepted scientific understanding. More interestingly, only five out of eight science teachers in 1998 agreed that they could help students interpret their results.

Although there was a general lack of familiarity with the specifics of the science standards, responses to several questions indicated that the educators supported many of the concepts advocated in the standards. These include recognition that students should be taught using a hands-on approach and that this approach does not interfere with the learning of content. A large proportion (93\%) of the educators indicated that connections need to be made between science concepts and real-world applications. Eighty percent indicated that students also learn best when they struggle with real-world problems. All science teachers and nearly $90 \%$ of all the participants indicated that it was also important to take students' conceptions about natural phenomena into account when planning curricula. However, less than one-half of the responses indicated that students should help design course content by voicing their opinions about how and what they should learn in the classroom.

\section{DISCUSSION}

The number of teachers participating in the workshops was kept low because we were treating this as a pilot project from which to learn and develop a high-quality workshop experience that others could model. The relatively small number of participants may limit the applicability of our results to larger populations. However, for our sample population, our data clearly indicate that our workshop met our goals and objectives as well as being well received and helpful to the teachers. More than $90 \%$ of the teachers indicated that they would go back to their schools and discuss what they learned with other teachers. Incidently, discussions initiated by one of the participating social studies teachers from a rural school district prompted the modification of their K-12 social-studies curriculum.

Providing time for curriculum planning was critical because participants are not necessarily given the opportunity to work with other teachers from different disciplines to develop interdisciplinary units. One participant commented that "This will be the first time I have ever had the opportunity to work in the classroom with another teacher." Another said that "it (the workshop) provided compensated time to work with a colleague in developing curriculum. This seldom, if ever, happens in our school setting." If we are to take advantage of one of the most beneficial objectives in the national vision for science education, the integration of science concepts with other areas of the curriculum, then professional development opportunities for educators need to be developed at the school level. This allows interdisciplinary curriculum to be developed that is also consistent with local curriculum goals and objectives. 


\section{Process-Oriented Environmental Change Curriculum-Development Workshops}

One goal of the K-12 science standards is that students be able to think and analyze in terms of systems. The application of a systems approach is not new. Scientists, teachers, and students recognize that the natural world is too large and complicated to investigate and comprehend all at once, so they choose to examine small parts for the convenience of investigation and understanding. However, addressing an issue such as global change, or for that matter any environmental issue, requires an understanding of how the parts or subsystems of the earth interact. According to our qualitative data, the concept of systems was presented in a workable manner. Several participants noted they liked the systems approach because it provided the framework necessary to look at environmental change with a broader focus and helped them recognize that "everything is connected to everything else."

Another principle that is guiding the reformation of science education is that learning science is an active process. Over three-quarters of the educators indicated that the active learning environment provided by the workshop leaders was consistent with what they individually try to provide for their students. Modeling a hands-on approach to earth science not only gave teachers experience with data collection activities but, as several participants noted, "provided great ideas to use with students."

Although hands-on experiences are an integral part to active learning, science teaching also needs to engage the brain and involve students in inquiry-oriented investigations. Inquiry-oriented science education allows students to become part of the scientific process. By scientific process, we mean the ability to investigate, to think critically, to use one's imagination, intuition, and playfulness, and to think on one's feet and with one's hands (Bower, 1996). With this approach, learning science becomes active and participatory and not something that is passive or sedentary. There is no more effective way to convey the excitement of science than for teachers and their students to really "do" science when the process requires open-ended, inquiry-based, student-driven exploration of a topic. These skills are not just limited to scientific inquiry but apply also to bringing creative approaches to problem solving that can be incorporated into other aspects of everyday life.

Although the teachers are trying to engage their students in "active learning," fewer than $60 \%$ of our participants agreed that they are confident in their ability to interpret results consistent with accepted scientific understanding. This result is not surprising considering that the majority of teachers have not had the opportunity to work with data or to provide their own interpretations. To acquire these skills requires experience and training that is generally not available to educators. A critical benefit of this workshop was the opportunity for the teachers to develop and practices these skills. We spent a significant amount of time explicitly discussing uncertainty in science through group discussions and problem-solving activities. Even though they may have lacked confi- dence at this point, they apparently did gain valuable experience.

We clearly need to find ways to boost teacher confidence in interpreting data using accepted scientific practice if implementation of the standards is going to take place. To boost confidence, future and current science teachers need to have meaningful scientific research experiences early and then throughout their academic careers.

Because the teachers do not have confidence in their scientific process skills, it is not surprising that they do not understand how to create a unit on global environmental change that implements the national or state standards. Research literature on teacher change indicates they have difficulty translating standards into meaningful lessons for a variety of reasons including lack of knowledge, as well as beliefs about what is important knowledge for students to learn, and how students learn (Richardson, 1990). Our group of teachers seems to mirror that finding where only about half of the science teachers reported they understood how to create a unit implementing standards. Providing examples for teachers to change their classroom practice is critical to implementing the vision of the standards. Our participants suggested that in future workshops, time should be provided to discuss how other teachers have managed implementation.

One area of concern during the 1998 workshop was the nature of the interdisciplinary organization. Some teachers felt that they needed more preparation to understand the scientific concepts and terminology. Others felt the content was too biased toward science and should contain more social-science information. We consider this a very positive development because it indicates that the participating teachers are beginning to understand the problems with teaching an interdisciplinary unit and are seeking different perspectives and additional information. We are considering the addition of a non-science member to the teaching team as well as developing a glossary and/or web site of scientific definitions and terminology to address these concerns. We will also strongly encourage the non-science teachers to bring and present materials on the standards that are relevant to their disciplines. This will provide an opportunity for the science teachers to become familiar with the expectations that other teachers face. In addition, it will assist with the development of a curriculum unit that is consistent with both sets of standards.

\section{RECOMMENDATIONS FOR PROFESSIONAL DEVELOPMENT WORKSHOPS}

Our workshop represents one type of professionaldevelopment activity that supports the vision of the National Science Education Standards and provides a model for incorporating environmental change data and concepts into current K-12 curriculum. Our recommendations are consistent with those provided by Darling-Hammond (1998).

We recommend that the following components be included as keys to a successful interdisciplinary professional development workshop: 


\section{Process-Oriented Environmental Change Curriculum-Development Workshops}

1) Commit to creating a learning environment in which the scientific process is modeled.

2) Provide opportunities to help teachers use technology in new ways.

3) Help teachers access locally relevant environmental change information and data.

4) Provide activities and opportunities that create a collegial environment.

5) Present the concept of systems as the framework necessary to look at environmental change with a broader focus.

6) Require teams of teachers that include at least one earth science teacher and at least one teacher from another discipline.

7) Provide planning time for teachers to work together.

8) Use the National Science Education Standards to provide the criteria for workshop development.

9) Use daily formative assessment to address the participant's concerns and thoughts.

10) Develop activities to boost teacher confidence in using data in the classroom.

\section{ACKNOWLEDGMENTS}

This research was funded by the US Department of Energy's (DOE) National Institute for Global Environmental Change (NIGEC) through the NIGEC Great Plains Regional Center at the University of Nebraska - Lincoln. (DOE Cooperative Agreement No. DE-FC03-90ER61010.) Financial support does not constitute an endorsement by DOE of the views expressed in this article/report. Reviews by K. Dewey, M. Hayes and an anonymous reviewer helped improve the manuscript. This is journal series paper, 99-3-5 of the University of Nebraska Agriculture Experiment Station.

\section{REFERENCES CITED}

American Geological Institute (AGI), 1991, Earth Science Education for the 21st Century: A planning guide: Alexandria, Virginia.

Bower, J.M., 1996, Science education reform: How can we help?: Issues in Science and Technology, p. 55-60.

Darling-Hammond, L., 1998, Teacher learning that supports student learning: Educational Leadership, v. 55, p. 6-11.

Geary, E., and Zen, E., 1993, A summary of the first presidential conference on earth science education: GSA Today, v. 3, p. 86-87.

Gosselin, D.C., 1994, Nebraska Earth Science Education Network (abstract): Coalition for Earth Science Meeting, Reston, Virginia, March 4-6.

Gosselin, D.C., Wright, J.L., Matherne, A.M., Mohlman, D.R., and Belohlavy, F.V., 1995a, The Nebraska earth science education network initiative, Journal of Geological Education, v. 43, p. 26-28.

Gosselin, D.C., 1995b, Nebraska Net Links Teachers: Geotimes, v. 40, p. 5.

Gosselin, D.C., 1995c, Nebraska Earth Science Education Network (NESEN): A State Geological Survey Enhancing the University-Teacher Connection (abstract): Geological
Society of America Annual Meeting, New Orleans, Louisiana, November 4-8.

Gosselin, D.C., Mohlman, D., Mesarch, M.A., and Meyer, S.J., 1996, Nebraska Earth Science Education Network: A university-teacher connection: Science Education International, v. 7, p. 5-8.

Gosselin, D.C., Mohlman, D.R., Meyer, S.J., Mesarch, M.A., and Lang, B.P., 1997, Nebraska Earth Science Education Network (NESEN): Connecting University Resources and Earth Science Educators (abstract): GeoSciEd II, Second International Conference on Geoscience Education, University of Hawaii-Hilo, p. 63-64.

Gosselin, D.C. and others, 1998. The Nebraska Earth Science Education Network Electronic Communication Project: Journal of Geoscience Education, v. 47, p. 12-16.

Groat, C.G., 1995. If only Dick and Jane had gone to the mines, Key Note Address, Proceedings of the Midcontinent Industrial Minerals Workshop: U.S. Geological Survey Bulletin 2111, p. 67-71.

Ireton, M.F.W., Manduca, C.A., and Mogk, D.W., 1996, Shaping the future of undergraduate earth science education: Innovation and change using an Earth System Approach: Report of a workshop convened by the American Geophysical Union in cooperation with the Keck Geology Consortium and with support from the National Science Foundation, $61 \mathrm{p}$.

Lowrey S., 1998, Global Environmental Change Workshop 1997: Evaluation Report, 12 p., plus 3 appendices.

Lowrey S., 1999, Global Environmental Change Workshop 1998: Evaluation Report, 12 p., plus 3 appendices.

Mayer, V.J., and Armstrong, R.E., 1990, What every 17year old should know about planet earth: The report of a conference of educators and geoscientists: Science Education, v. 74, p. 102-107.

Metzger, E.P., 1993, The STRATegy COLUMN for precollege science teachers: Journal of Geological Education, v. 41, p. 294-296.

National Research Council, 1996a, National Science Education Standards: Washington D.C., National Academy Press, $262 \mathrm{p}$

National Research Council, 1996b. Center for Science, Mathematics and Engineering Education: From Analysis to Action, Undergraduate Education In Science, Mathematics, Engineering, And Technology; A report of a convocation: Washington D.C., National Academy Press, 38 p.

National Science Foundation (NSF) 97-171, 1997, Geoscience Education: A Recommended Strategy. A report based on an August 29-30, 1996, Workshop form the Geoscience Education Working Group to the Advisory Committee for Geosciences and the Directorate for Geosciences of the National Science Foundation, 35 p.

\section{About the Authors}

David Charles Gosselin is director of the $\mathrm{Ne}^{-}$ braska Earth Science Education Network and associate professor with the School of Natural Resource Sciences and Conservation and Survey Division at the University of Nebraska-Lincoln.

Steven John Meyer is an assistant professor in the School of Natural Resource Sciences at the University of Nebraska-Lincoln.

Sherri Lowrey has a BS in Science Education from Kansas State University. She received her $\mathrm{MA}$ and is currently working on a $\mathrm{PhD}$ in psychology from University of Nebraska-Lincoln. 
Richardson, V., 1990, Significant and worthwhile change in teaching practice: Educational Researcher, v. 10, p. 10-18.

Sneider, C., and Golden, R., 1996, Global systems science: a new world view: Lawrence Hall of Science; University of California, Berkeley, California, 29 p. 